\title{
Actions improving the image of a nurse in electronic media. Opinion of students at medical courses
}

Działania poprawiające wizerunek pielęgniarki w mediach elektronicznych. Opinia młodzieży studiującej na kierunkach medycznych

\section{Klaudia Jakubowska ${ }^{1}$, Anna Sykut ${ }^{2}$}

'Katedra Rozwoju Pielęgniarstwa, Wydział Nauk o Zdrowiu, Uniwersytet Medyczny w Lublinie/ Chair of Development in Nursing, Faculty of Health Sciences, Medical University of Lublin ZZakład Medycyny Rodzinnej i Pielęgniarstwa Środowiskowego, Katedra Onkologii i Środowiskowej Opieki Zdrowotnej Wydział Nauk o Zdrowiu, Uniwersytet Medyczny w Lublinie/Department of Family Medicine and Environmental Nursing Department of Oncology and Environmental Health Care, Faculty of Health Sciences, Medical University of Lublin

CORRESPONDING AUTHOR/AUTOR DO KORESPONDENCJI:

Klaudia Jakubowska

Katedra Rozwoju Pielęgniarstwa Wydział Nauk o Zdrowiu UM w Lublinie

ul. Staszica 4/6, 20-250 Lublin e-mail: klau.jakubowska@gmail.com

STRESZCZENIE

Słowa kluczowe:

ABSTRACT
DZIAKANIA POPRAWIAJACE WIZERUNEK PIELEZGNIARKI W MEDIACH ELEKTRONICZNYCH. OPINIA MRODZLIZY STUDIOJACE NA KIERUNKACH MEDYCZNYCH

Cel pracy. Celem pracy było określenie działań mających na celu poprawę wizerunku pielęgniarek w mediach elektronicznych. Materiał i metodyka. W badaniu ankietowym wzięło udział 219 kobiet i 44 mężczyzn, studentów kierunków: pielęgniarstwo, ratownictwo medyczne, położnictwo, lekarski, stomatologa, farmacja, fizjoterapia, zdrowie publiczne. Badania zostały przeprowadzone z wykorzystaniem autorskiego kwestionariusza ankiety w 2015 roku.

Wyniki. Większość badanych 64,6\% (n=169) było zdania, że poprawa wizerunku zawodu pielęgniarki należy do samych pielęgniarek i pielęgniarzy, tylko 35,4\% (n=93) ankietowanych wskazało na rolę organizacji zawodowych pielęgniarek i położnych. Według 72,2\% ( $\mathrm{n}=189$ ) badanych studentów najważniejszym zadaniem, które powinny przedsięwziąć organizacje zawodowe w celu poprawy wizerunku zawodu w mediach elektronicznych były poprawa płac i warunków pracy oraz większa promocja zawodu w mediach elektronicznych $(73,8 \%, n=193)$. Pielęgniarki mogą wpływać na poprawę swojego wizerunku w mediach dbając o dobrą opinię o zawodzie poprzez własny przykład (32\%, n=84), a także tworzenie np. blogów, forów społecznościowych, internetowych serwisów informacyjnych $(26,2 \%, \mathrm{n}=69)$.

Wnioski. Według badanych wizerunek pielęgniarki w mediach elektronicznych kształtowany jest przez telewizję i radio. Wymienione media przedstawiają środowisko pielęgniarskie w złym świetle. Z analizy danych wynika, iż zdaniem respondentów odpowiedzialnymi za poprawę sytuacji powinny być organizacje zawodowe pielęgniarek i położnych oraz same pielęgniarki i pielęgniarze. W celu poprawy wizerunku zawodu pielęgniarki powinny promować osiągnięcia zawodowe, zmieniać stereotyp pielęgnowania prezentowany w serialach i filmach oraz zapoznawać społeczeństwo z profesją zawodu. Należy wykorzystać różne rodzaje mass mediów takie jak: strony internetowe, telewizję i radio do promowania najlepszych cech zawodu.

wizerunek zawodowy, media elektroniczne, studenci pielęgniarstwa, pielęgniarki polskie, poprawa wizerunku

\section{AACTIONS IMPROVING THE IMAGE OF A NURSE IN ELECTRONIC MEDIA.} OPINION OF STUDENIS AT MEDICAL COURSES

Aim. The aim of study was to define actions improving the image of nurses in electronic media.

Material and method. 219 women and 44 men took part in a survey. They were the students of the following courses: nursing, medical rescue, obstetrics, medicine, dentistry, pharmaceutics, physiotherapy, public health. The studies were undertaken with use of own questionnaire in 2015.

Results. Majority of respondents $64,6 \%(n=169)$ stated that improvement of image of their own profession belongs to the nurses, and only $35,4 \%$ ( $n=93$ ) respondents indicated that the professional organizations of nurses and midwives have their impact on it. According to the students, the most crucial action that should be undertaken by professional organizations in order to improve the image of profession in electronic media was the improvement of wages and working conditions $(72,2 \%, n=189)$ and better promotion of the profession in electronic media $(73,8 \%, \mathrm{n}=193)$. The nurses can influence the improvement of their image in media by taking care of the good opinion about the profession by setting good example $(32 \%, n=84)$, and also by creating blogs, social forum, online information services, etc. $(26,2 \%, n=69)$. 
Conclusions. According to the respondents, the image of a nurse in electronic media is shaped by the television and radio. The mentioned media tend to present nursing environment in a negative light. The data analysis shows that according to the respondents, the professional organizations of nurses and midwives and nurses themselves should be responsible for improvement of the situation. In order to improve the image, the nurses should promote professional achievements, change the stereotype used in shows and movies, and familiarize the public with the profession. The following branches of mass media should be used: internet websites, television and radio.

Key words: $\quad$ professional image, electronic media, nursing students, Polish nurses, improving the image

\section{INTRODUCTION}

Contemporarily mass media constitutes significant means of education and socialization [1]. The content of the media can be both positive and negative [2]. Therefore, the Nursing professional group should make sure that reports about them stem directly from the representatives of this profession with the conscious use of social media. Television, the radio or the Internet affect the consciousness of the audience intensely. They are in power to modify actions, attitudes, and even emotions and motivation of large groups of people.

Since the image is never a faithful copy of the imagined object, the perception process is a subjective and active one. These features make the image freely shaped, following the wish of its creator. By providing an individual with specific, selected information and impressions on a particular subject, we are able to influence the image created by that individual so that it will determine its behavior towards that subject [3].

The studies by Grabska and Stefanska show that out of 90 patients, $76 \%$ of the respondents declared trust in nurses [4]. The latest survey conducted in 2013 by the Center for Public Opinion Research, which determines the prestige of particular professions, shows that Nurses are ranked 6th as a profession enjoying great social usefulness [5]. Nevertheless, they have not reached the $1^{\text {st }}$ rank yet, as is the case of the survey results conducted in the USA by Gallup Institute. In 2013 Nurses were on the $1^{\text {st }}$ rank as the profession with the highest social trust and they have been maintaining this status since then [6].

Over the years, the public opinion on the status of different professions has been dynamic in nature, nurses should take advantage of the fact. The mass media is of a vital importance in that case.

\section{AIM}

The aim of the study was to identify specific actions leading to the improvement of the professional image of nurses in electronic media in the opinion of young people studying in medical fields.

\section{MATERIALS AND METHODS}

The diagnostic survey method and the questionnaire were used for the purpose of this study. A survey questionnaire consisting of 30 semi-open questions was used, and it was developed as part of the activity of Studenckie Koło Naukowe przy Katedrze Rozwoju Pielęgniarstwa/ the Student Research Club at the Department of Development in Nursing. The anonymous study carried out in 2015 was attended by 262 students (100\%) of the following medical fields: nursing $(\mathrm{n}=77,29.4 \%)$, medical rescue $(\mathrm{n}=30$, $11.5 \%)$, obstetrics $(n=30$, medicine $(n=30,11.5 \%)$, dentistry $(n=30,11.5 \%)$, pharmacy $(n=31,11.8 \%)$, physiotherapy $(\mathrm{n}=32,12.2 \%)$, public health $(\mathrm{n}=2$, $0.8 \%$ ) [Fig. 1.]. The respondents were carefully selected due to their affiliation to the therapeutic team and close collaboration with the nurses.

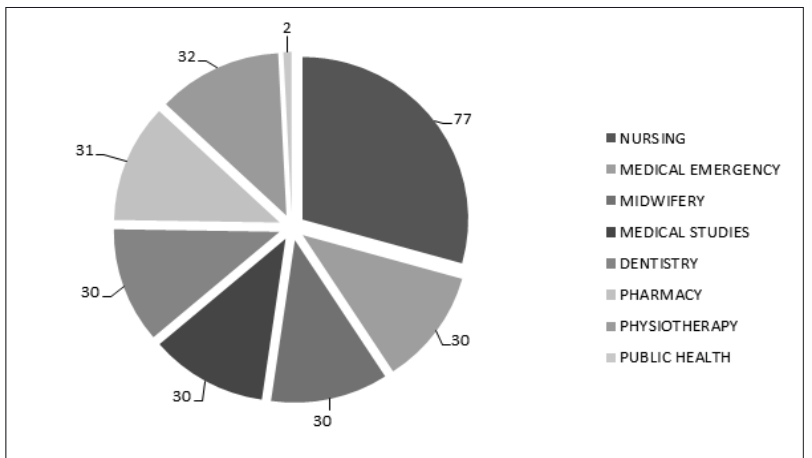

Fig. 1. The subject studied by the surveyed students

During the study, the students used the website www. moje-ankiety.pl where the questionnaire was posted. For statistical analysis, IBM SPSS Statistics version 21 was used.

The study was conducted in accordance with the principles of the Declaration of Helsinki. Each respondent invited to participate in the study was informed about the purpose of the study and assured the total anonymity of the study process and the data collected as well as the possibility of withdrawing from the study.

\section{RESULTS}

Out of the 262 respondents 219 were women (83.3\%), and 44 were men $(16.7 \%)$. The average age of the respondents was 24 years old $(\mathrm{AD}=2.85)$. The youngest of them was 19 years old, and the oldest one 48 years old. The largest group of the respondents studied nursing (29.4\%, $\mathrm{n}=77)$.

The results of the study show that $13.7 \%(n=36)$ of the respondents considered the status of a nurse profession among medical professions to be very high, and 29.3\% $(n=77)$ considered it to be too high. One-third of the respondents rated the status of a nurse profession as an average one $(35.7 \%, \mathrm{n}=94)$.

Every fifth respondent stated that this status was low $(19.0 \%, \mathrm{n}=50)$. In addition, $1.5 \%(\mathrm{n}=4)$ rated it as very low, and $0.8 \%(\mathrm{n}=2)$ did not comment on it. 
In the opinion of the surveyed who study in the medical field, electronic media has a very high $(41.8 \%, \mathrm{n}=110)$ or high $(31.6 \%, \mathrm{n}=83)$ impact on the image of a nurse profession. In general, the respondents were of the opinion that both television and the radio presented the nursing environment in a bad light.

The worst message, in the opinion of the respondents, is broadcast by television $(74 \%, \mathrm{n}=182)$. More than half of the surveyed students $(57.8 \%, \mathrm{n}=152)$ believed that the news and reports from the world had the greatest influence on building the image of a nurse profession. The selected program type was found to be unfavourable by $64.3 \%(n=169)$. Pharmacy students believed that television had a more positive effect on image building. The unfavourable one was more often selected by nursing students. Almost one-third of the respondents said that the influence of the radio on image building was insignificant $(30 \%, n=79)$. The subject of studies varies the answers. In opposition to dentistry students, physiotherapy students stated that the radio had a more beneficial effect on image building. Interestingly, the respondents were of the opinion that the Internet was more likely to present the profession of a nurse in a good light $(55.6 \%, \mathrm{n}=70)$ than in a negative one $(44.4 \%, \mathrm{n}=55)$. The image of a nurse presented on websites $(28.5 \%, \mathrm{n}=75)$ had, in the opinion of the respondents, the greatest influence on image building. The respondents, who rated the impact of the Internet on a nurse image as very high $(47.1 \%, \mathrm{n}=124)$ and high $(36.1 \%, \mathrm{n}=95)$ constituted a great majority of the surveyed. This effect in $31.6 \%(n=83)$ was found to be favourable. Considering the opinion of particular subjects, pharmacy students believed that the Internet had a more positive impact on image building. Dentistry and medicine students mostly believed that this effect was unfavorable.

The most widespread element of the image of a nurse on television as seen by the respondents is strikes $(75.1 \%$, $\mathrm{n}=187$ ). In addition, television also draws the attention to protests $(65 \%, \mathrm{n}=171)$ and to the fact that the profession of a nurse is worse than the profession of a doctor $(65 \%$, $\mathrm{n}=171)$, and that it is also underestimated $(68.1 \%$, $\mathrm{n}=179$ ). In order to improve the image on television, students, first of all, pointed out the promotion of professional achievements $(86.7 \%, \mathrm{n}=228)$, the change of the image stereotype used in films and TV series $(77.6 \%$, $\mathrm{n}=204$ ) and becoming familiar with the profession of a nurse $(75.3 \%, \mathrm{n}=198)$ [Tab. 1.].

In the opinion of the surveyed, the radio also reports on strikes and protests from nurses $(55.1 \%, \mathrm{n}=145)$. However, the topics of errors made by nurses $(27.0 \%$, $\mathrm{n}=71)$ and the shortage in employment $(33.5 \%, \mathrm{n}=88)$ are presented in a different way from the one on television. Improving the image of a nurse can be achieved by promoting professional achievement $(81.7 \%, \mathrm{n}=215)$, stereotype change $(73 \%, \mathrm{n}=192)$ and familiarizing with the profession of a nurse $(72.2 \%, \mathrm{n}=190)$. Slightly less frequently, the respondents focused on the promotion of daily work $(65 \%, \mathrm{n}=171)$ [Tab.2.].
Tab. 1. The opinion of the respondents on actions aimed at improving the image on television

\begin{tabular}{|l|c|c|c|c|c|c|}
\hline \multirow{2}{*}{$\begin{array}{l}\text { Actions aimed at improving the } \\
\text { image of nurses on the television }\end{array}$} & \multicolumn{5}{|c|}{ Rating } \\
\cline { 2 - 7 } & & 1 & 2 & 3 & 4 & 5 \\
\hline \multirow{2}{*}{$\begin{array}{l}\text { Promoting professional } \\
\text { achievements }\end{array}$} & $\mathrm{n}$ & 228 & 29 & 4 & 2 & 0 \\
\hline & $\%$ & 86.7 & 11.0 & 1.5 & 0.8 & 0 \\
\hline $\begin{array}{l}\text { Changing the stereotype image } \\
\text { used in movies and TV series }\end{array}$ & $\mathrm{n}$ & 204 & 43 & 8 & 6 & 2 \\
\cline { 2 - 7 } & $\%$ & 77.6 & 16.3 & 3.0 & 2.3 & 0.8 \\
\hline $\begin{array}{l}\text { Familiarization with the } \\
\text { profession of nurse }\end{array}$ & $\mathrm{n}$ & 198 & 46 & 15 & 3 & 1 \\
\cline { 2 - 7 } & $\%$ & 75.3 & 17.5 & 5.7 & 1.1 & 0.4 \\
\hline Promoting everyday work & $\mathrm{n}$ & 179 & 69 & 10 & 4 & 1 \\
\cline { 2 - 7 } & $\%$ & 68.1 & 26.2 & 3.8 & 1.5 & 0.4 \\
\hline $\begin{array}{l}\text { Presenting conversations with } \\
\text { the patient }\end{array}$ & $\mathrm{n}$ & 172 & 54 & 28 & 7 & 2 \\
\cline { 2 - 7 } & $\%$ & 65.4 & 20.5 & 10.6 & 2.7 & 0.8 \\
\hline $\begin{array}{l}\text { Presenting talks with other } \\
\text { representatives of the health care } \\
\text { /medical professionals }\end{array}$ & $\mathrm{n}$ & 154 & 63 & 33 & 11 & 2 \\
\cline { 2 - 7 } & $\%$ & 58.6 & 24.0 & 12.5 & 4.2 & 0.8 \\
\hline
\end{tabular}

1 - Definitely yes, 2 - Rather yes, 3 - I have no opinion, 4 - Not quite, 5 - Definitely not

Tab. 2. The opinion of the respondents on actions aimed at improving the image on the radio

\begin{tabular}{|l|c|c|c|c|c|c|}
\hline \multirow{2}{*}{$\begin{array}{l}\text { Actions aimed at improving } \\
\text { the image of nurses on the radio }\end{array}$} & \multicolumn{6}{|c|}{ Rating } \\
\cline { 2 - 7 } & 1 & 2 & 3 & 4 & 5 \\
\hline $\begin{array}{l}\text { Promoting professional } \\
\text { achievements }\end{array}$ & $\mathrm{n}$ & 215 & 36 & 12 & 0 & 0 \\
\cline { 2 - 7 } & $\%$ & 81.7 & 13.7 & 4.6 & 0 & 0 \\
\hline $\begin{array}{l}\text { Changing the stereotype image } \\
\text { used in movies and TV series }\end{array}$ & $\mathrm{n}$ & 192 & 45 & 17 & 7 & 2 \\
\cline { 2 - 7 } & $\%$ & 73.0 & 17.1 & 6.5 & 2.7 & 0.8 \\
\hline Familiarization with the & $\mathrm{n}$ & 190 & 51 & 18 & 3 & 1 \\
\cline { 2 - 7 } profession of nurse & $\%$ & 72.2 & 19.4 & 6.8 & 1.1 & 0.4 \\
\hline Promoting everyday work & $\mathrm{n}$ & 171 & 70 & 15 & 6 & 1 \\
\cline { 2 - 7 } & $\%$ & 65.0 & 26.6 & 5.7 & 2.3 & 0.4 \\
\hline $\begin{array}{l}\text { Presenting conversations with } \\
\text { the patient }\end{array}$ & $\mathrm{n}$ & 168 & 57 & 27 & 9 & 2 \\
\cline { 2 - 7 } & $\%$ & 63.9 & 21.7 & 10.3 & 3.4 & 0.8 \\
\hline $\begin{array}{l}\text { Presenting talks with other } \\
\text { representatives of the health care } \\
\text { / medical professionals }\end{array}$ & $\mathrm{n}$ & 151 & 67 & 31 & 11 & 3 \\
\cline { 2 - 7 } & $\%$ & 57.4 & 25.5 & 11.8 & 4.2 & 1.1 \\
\hline
\end{tabular}

$\mathrm{n}$ - number of respondents in this category

1 - Definitely yes, 2 - Rather yes, 3 - I have no opinion, 4 - Not quite, 5 - Definitely not

The highest number of respondents indicated that the most frequently reported information about nurses on the Internet is their strikes $(75.7 \%, \mathrm{n}=199)$. A significant percentage of the respondents pointed out the lack of nursing employment $(70.7 \%, \mathrm{n}=186)$. According to the respondents, the improvement of the image of a nurse, as is the case of the other electronic media, can be achieved by promoting professional achievements $(85.9 \%, \mathrm{n}=226)$, stereotype change $(76 \%, \mathrm{n}=200)$ and familiarizing with the profession of a nurse $(76 \%, \mathrm{n}=205)$. Slightly less frequently the respondents pointed to the promotion of daily work $(71.5 \%, \mathrm{n}=188)$ [Tab. 3.].

The majority of the respondents noted accessibility as an important aspect of constructing a website or another tool. Every fourth respondent pointed out the popularity $(24.3 \%, \mathrm{n}=64)$, and every fifth legibility and originality $(20.4, \mathrm{n}=37)$. In addition, $14.4 \%(\mathrm{n}=38)$ noted the activity and the relevance of the information [Tab.4.].

Most of the respondents $(64.6 \%, n=169)$ believed that representatives of the profession themselves, and not professional organizations of nurses and midwives 
Tab. 3. The opinion of respondents on measures to improve the image of the Internet

\begin{tabular}{|c|c|c|c|c|c|c|}
\hline \multirow{2}{*}{\multicolumn{2}{|c|}{$\begin{array}{l}\text { Actions aimed at improving the } \\
\text { image of nurses on the Internet }\end{array}$}} & \multicolumn{5}{|c|}{ Rating } \\
\hline & & \multirow{2}{*}{$\frac{1}{226}$} & \multirow{2}{*}{$\begin{array}{c}2 \\
31 \\
\end{array}$} & \multirow{2}{*}{$\begin{array}{l}3 \\
6 \\
\end{array}$} & \multirow{2}{*}{$\begin{array}{l}4 \\
0\end{array}$} & \multirow{2}{*}{$\begin{array}{l}5 \\
0 \\
\end{array}$} \\
\hline Promoting professional & $\mathrm{n}$ & & & & & \\
\hline achievements & $\%$ & 85.9 & 11.8 & 2.3 & 0 & 0 \\
\hline \multirow{2}{*}{$\begin{array}{l}\text { Changing the stereotype image } \\
\text { used in movies and TV series }\end{array}$} & $\mathrm{n}$ & 200 & 50 & 8 & 3 & 2 \\
\hline & $\%$ & 76.0 & 19.0 & 3.0 & 1.1 & 0.8 \\
\hline \multirow{2}{*}{$\begin{array}{l}\text { Familiarization with the } \\
\text { profession of nurse }\end{array}$} & $\mathrm{n}$ & 205 & 43 & 9 & 5 & 1 \\
\hline & $\%$ & 77.9 & 16.3 & 3.4 & 1.9 & 0.4 \\
\hline \multirow{2}{*}{ Promoting everyday work } & $\mathrm{n}$ & 188 & 60 & 11 & 3 & 1 \\
\hline & $\%$ & 71.5 & 22.8 & 4.2 & 1.1 & 0.4 \\
\hline \multirow{2}{*}{$\begin{array}{l}\text { Presenting conversations with } \\
\text { the patient }\end{array}$} & $\mathrm{n}$ & 179 & 52 & 23 & 7 & 2 \\
\hline & $\%$ & 68.1 & 19.8 & 8.7 & 2.7 & 0.8 \\
\hline \multirow{2}{*}{$\begin{array}{l}\text { Presenting talks with other } \\
\text { representatives of the health care } \\
\text { /medical professionals }\end{array}$} & $\mathrm{n}$ & 162 & 60 & 31 & 8 & 2 \\
\hline & $\%$ & 61.6 & 22.8 & 11.8 & 3.0 & 0.8 \\
\hline
\end{tabular}

1- Definitely yes, 2 - Rather yes, 3 - I have no opinion, 4 - Not quite, 5 - Definitely not

Tab. 4. Opinion of respondents on the actions that can improve the image of the Internet

\begin{tabular}{|l|c|c|}
\hline The important aspects of building a website or other tool & $\mathrm{n}$ & $\%$ \\
\hline Readability and originality & 37 & 20.4 \\
\hline Popularity & 64 & 24.3 \\
\hline Availability & 83 & 31.6 \\
\hline Active and up-to-date information & 38 & 14.4 \\
\hline Other & 78 & 29.7 \\
\hline Total & 263 & 100.0 \\
\hline $\mathrm{n}$ - number of respondents in a given category
\end{tabular}

$(35.4 \%, \mathrm{n}=93)$ should be held responsible for improving the image of a nurse. 20 respondents $(7.6 \%)$ knew about social activities or the work of professional organizations to improve the image of the profession of a nurse.

According to the surveyed students, the most important task that should be taken into consideration by professional organizations to improve the image of the profession was to increase salaries and working conditions $(72.2 \%, \mathrm{n}=189)$ and to promote the profession more extensively in electronic media $(73.8 \%, \mathrm{n}=193)$, then to organize social campaigns $(64.3 \%, \mathrm{n}=168)$ and identify nurses with professional background $(64.3 \%, \mathrm{n}=168)$. The lowest importance was assigned to cooperation with PR firms $(49 \%, \mathrm{n}=128)$. According to the respondents, the tasks that nurses are due to perform to improve their image are: taking good care of their profession through their own example $(39.2 \%, \mathrm{n}=103)$ and creating $(26.2 \%$, $\mathrm{n}=69)$ e.g. blogs, forums, online information services. $13.3 \%(\mathrm{n}=35)$ believed that it was possible to improve the image by involvement in professional organizations.

\section{DISCUSSION}

The opinion-forming role of social media creates the environment that favours shaping or influencing views to a large extent. The media is the decision maker on what and how it will be published and what degree of importance given information is to convey [7]. DobekOstrowska points out that one of the rights of a citizen in a democratic state is the freedom of expressing one's own views supported by the right to fair information. The way to implement this principle by the media is determined by legal norms [8]. The right to freedom of expression is protected by the Convention for the Protection of Human Rights and Fundamental Freedoms, and by the Constitution of the Republic of Poland as well as the Press Law $[9,10]$. The journalist is obliged to act in accordance with professional ethics, utmost diligence and accuracy. The degree of diligence of a journalist may vary. Therefore, when a professionally trained nurse makes a mistake while working with a patient, it is important to remember that the reason for this can be described by a journalist with the use of whatever mechanism they choose. The mass media can play a role of a service but the necessary condition of its success is making a good use of it.

Most of the respondents $(64.6 \%)$ believed that it was the nurses and male nurses who were obliged to improve the image of their profession. The data is reflected in the results of the study by Sobczak and Kamińska, where the respondents perceive the professional status of a nurse as defined by the type of actions undertaken. A highly significant correlation ( $\operatorname{chi} 2=24.46, \mathrm{df}=4, \mathrm{p}<0.0001)$ of the division of the response into the question "Please indicate which of the listed nursing activities has the greatest impact on improving their professional status?" was found. In the group of students the most common answer was "social" (54\%), and among the students of the University of the Third Age the most common answer was the "scientific" option (37\%) [11]. Similarly, Kołodziej points out that factors such as better and better education, graduation or the progress of medicine posing new challenges to nurses are a lever that helps to improve the social and professional status of this profession [12]. In their own studies, the respondents believed that the improvement of the image of a nurse was possible to achieve, primarily through the promotion of professional achievements (86.7\%), the change of a stereotypical image used in films and TV series (77.6\%), and becoming familiarized with the profession of a nurse (75.3\%). The above study shows it is nurses themselves who must earn the ethos of their profession, since the status of the profession and respect for it are built primarily by the high level of competence and professionalism [13]. It is very important to define a specific aim which nurses want to pursue without, at the same time, forgetting the tradition of the profession [14].

Despite the available media tools, there is a noticeable lack of the use of the mass media to increase the status of a nursing profession. The confirmation of that is included in the studies made by Sykut and Dobrowolska, who point out that only 24 professionally trained nurses (13.3\%) were aware of the social actions or activities of the organization aiming to improve the image of the profession [15]. Similarly, the study involving nursing students (29\%) shows that social actions concerning the improvement of the image of Nurses are unknown to a great number of the respondents $(7.2 \%)$.

In addition, the students pointed out that both television and radio present the nursing environment in a bad light. The worst message, in the opinion of the respon- 
dents, is broadcast by television (74\%). It is crucial to keep in mind that widespread publicity on errors or other negative reports can quickly lead to distrust and even hostility [16].

The extent of the influence of the media on public opinion is primarily the degree of knowledge and awareness of a given group. Television has an influence on our way of thinking and behaviour, it can cause anger, tears and joy, it makes us think, it provokes feelings and motivates us to act. Cleverly uttered and concise words very often make the recipient of the message lose self-awareness and individualism, so that they begin to use slogans. The recipient begins to focus only on the events that are presented by the mass media often without the sense of obligation to seek the truth. This is another reason why the mass media should be the main tool for improving the image of Nurses. There were also respondents who considered more extensive advertising in the electronic media $(73.8 \%)$ to be a prescription for prestige improvement. That was to be followed by the organisation of social campaigns $(64.3 \%)$, and one in four $(26.2 \%)$ believed that creating e.g. blogs, forums, and online information services would be influential.

Mary Adelaide Nutting, the world's first Nursing Professor once said, "Nursing is one of the most difficult arts. Compassion can provide motivation, but knowledge is our only strength and driving force for work" [17]. In the light of those words, a professional group of Nurses must share solid and authentic knowledge with the public, trying to be ahead of the media, but at the same time making use of it. The mass media should not use the knowledge of Nursing in their own advertising. It is Nurses who ought to use the media to make their image far from television or online stereotypes.

\section{CONCLUSIONS}

1. One-third of the respondents rated the status of a nurse as an average one. This situation is largely caused by the electronic media, which in respondents' opinion, has a very high or high impact on the image of the profession of a nurse.

2. In essence, the respondents were of the opinion that both television and the radio present the nursing environment in a bad light. The worst message is broadcast by television, specifically, the news and reports from the world.

3. According to the respondents, it is the professional organizations of nurses and midwives that are responsible for the improvement of the situation, and so are the nurses and male nurses themselves.

4. Nurses should promote professional achievement, change the stereotype presented in the TV series and films, and also familiarize the public with the profession. For that reason, the mass media, such as websites, television and the radio should be used.

\section{Działania poprawiające wizerunek pielęgniarki w mediach elektronicznych. Opinia młodzieży studiującej na kierunkach medycznych}

\section{WSTĘP}

Mass media stanowią współcześnie istotne środki edukacji i socjalizacji [1]. Treść przekazu medialnego może mieć oblicze zarówno pozytywne jak i negatywne [2]. Dlatego też, grupa zawodowa pielęgniarek szczególnie powinna zadbać o to, aby doniesienia na ich temat wypływały bezpośrednio od przedstawicieli tej profesji ze świadomym wykorzystaniem social mediów. Telewizja, radio czy Internet oddziałują na świadomość odbiorców intensywnie. Potrafią doprowadzić do modyfikacji działań, postaw, a nawet emocji i motywacji dużych grup ludzi.

Ponieważ wizerunek nie jest nigdy wierną kopią wyobrażanego przedmiotu, proces postrzegania ma charakter subiektywny i aktywny. Cechy te powodują, że wizerunek może być dowolnie, wedle życzenia jego twórcy ukształtowany. Poprzez dostarczenie jednostce określonych, wyselekcjonowanych informacji i wrażeń na temat konkretnego podmiotu jesteśmy w stanie wpłynąć na tworzony przez nią obraz, tak że będzie on wyznaczał jej zachowanie względem tego podmiotu [3].

Badania Grabskiej i Stefańskiej wskazują, iż z 90 pacjentów, zaufanie do pielęgniarek zadeklarowało 76\% badanych [4]. Z ostatniego sondażu przeprowadzonego w 2013 roku przez Centrum Badania Opinii Społecznej, określającego prestiż poszczególnych zawodów wynika, że pielęgniarki zajmują 6. pozycję jako profesja, ciesząca się dużą użytecznością społeczną [5]. Niemniej jednak wciąż nie jest to 1 . miejsce jak w przypadku wyników badań przeprowadzonych w USA przez Instytut Gallup’a. W 2013 roku pielęgniarki znajdowały się na 1. miejscu jako zawód cieszący się najwyższym zaufaniem społecznym i wciąż utrzymują tę pozycję [6].

W przeciągu lat opinia społeczna na temat rangi różnych zawodów ma charakter dynamiczny, pielęgniarki powinny to wykorzystać. Istotne znaczenie mają środki masowego przekazu.

\section{CEL PRACY}

Celem pracy było określenie działań mających na celu poprawę wizerunku zawodowego pielęgniarek w mediach elektronicznych w opinii młodzieży studiującej na kierunkach medycznych. 


\section{MATERIAt I METODYKA}

W celu realizacji niniejszej pracy zastosowano metodę sondażu diagnostycznego i posłużono się techniką ankietowania. Wykorzystano kwestionariusz ankiety, który składał się z 30 pytań półotwartych i został opracowany w ramach prac Studenckiego Koła Naukowego przy Katedrze Rozwoju Pielęgniarstwa. W anonimowych badaniach przeprowadzonych w 2015 roku udział wzięło 262 studentów (100\%) następujących kierunków medycznych: pielęgniarstwo $(\mathrm{n}=77,29,4 \%)$, ratownictwo medyczne $(\mathrm{n}=30$, $11,5 \%)$, położnictwo $(\mathrm{n}=30,11,5 \%)$, lekarski $(\mathrm{n}=30$, $11,5 \%)$, stomatologia $(n=30,11,5 \%)$, farmacja $(n=31$, $11,8 \%)$, fizjoterapia ( $\mathrm{n}=32,12,2 \%)$, zdrowie publiczne $(\mathrm{n}=2,0,8 \%)$ [Ryc. 1.]. Respondenci zostali skrupulatnie dobrani, ze względu na przynależność do zespołu terapeutycznego i bliską współpracę z pielęgniarkami.

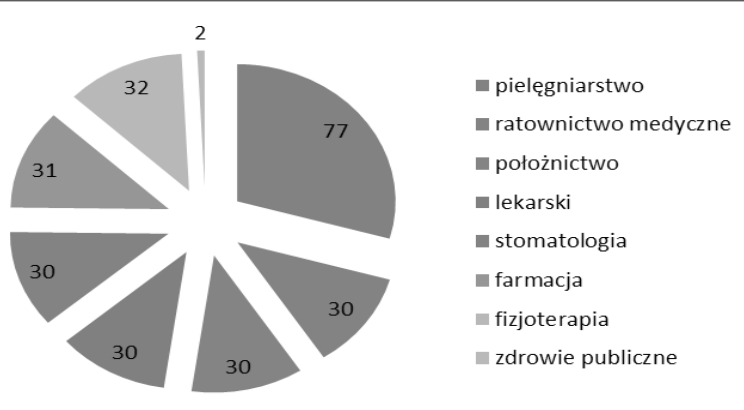

Ryc. 1. Kierunek studiów badanych studentów

W trakcie przeprowadzania badań studenci korzystali ze strony internetowej www.moje-ankiety.pl, gdzie został zamieszczony kwestionariusz. W celu analizy statystycznej posłużono się programem IBM SPSS Statistics wersja 21.

Badania przeprowadzono zgodnie z zasadami Deklaracji Helsińskiej. Każdy respondent zaproszony do udziału w badaniu został poinformowany o celu badań oraz zapewniony o całkowitej anonimowości przebiegu procesu badawczego i zgromadzonych danych, jak również o możliwości wycofania się z udziału w badaniach.

\section{WYNIKI BADAŃ}

Na 262 badanych 219 stanowiły kobiety (83,3\%), a 44 mężczyźni (16,7\%). Średni wiek badanych wyniósł 24 lata $(\mathrm{SD}=2,85)$. Najmłodszy badany miał 19 lat, najstarszy 48 lat. Najliczniejsza grupa badanych studiowała pielęgniarstwo $(29,4 \%, \mathrm{n}=77)$.

Z przeprowadzonych badań wynika, że 13,7\% (n = 36) badanych uważało pozycję zawodu pielęgniarskiego wśród zawodów medycznych za bardzo wysoką, zaś 29,3\% $(\mathrm{n}=77)$ uznało ją za wysoką. Jedna trzecia badanych oceniła pozycję zawodu pielęgniarskiego jako średnią (35,7\%, $\mathrm{n}=94)$. Co piąty badany określił, że ta pozycja jest niska $(19,0 \%, n=50)$. Ponadto $1,5 \%(n=4)$ oceniło ją jako bardzo niską, zaś $0,8 \%(\mathrm{n}=2)$ nie miało zdania na ten temat.

Według opinii badanych osób, które studiują na kierunkach medycznych media elektroniczne mają bardzo wysoki $(41,8 \%, \mathrm{n}=110)$ lub wysoki $(31,6 \%, \mathrm{n}=83)$ wpływ na wizerunek zawodu pielęgniarek. Zasadniczo respondenci byli zdania, że zarówno telewizja, jak i radio przedstawiają środowisko pielęgniarskie w złym świetle.

Najgorszy przekaz, w opinii badanych, wysyła telewizja $(74 \%, \mathrm{n}=182)$. Ponad połowa badanych studentów $(57,8 \%, n=152)$ była zdania, że największy wpływ na budowanie wizerunku zawodu pielęgniarki mają wiadomości i doniesienia ze świata. Większość respondentów $(64,3 \%, n=169)$ określiła wybrany rodzaj programu jako niekorzystny. Studenci farmacji uważali, że telewizja ma bardziej korzystny wpływ na budowanie wizerunku. Niekorzystny wpływ częściej był wybierany przez studentów pielęgniarstwa. Prawie jedna trzecia badanych, stwierdziła, że wpływ radia na budowanie wizerunku jest obojętny $(30 \%, n=79)$. Kierunek studiów różnicuje odpowiedzi. Studenci fizjoterapii określili, że radio ma bardziej korzystny wpływ na budowanie wizerunku, niż studenci stomatologii. Co ciekawe respondenci byli zdania, że Internet częściej przedstawia zawód pielęgniarki w dobrym świetle $(55,6 \%, \mathrm{n}=70)$, niżeli negatywnym $(44,4 \%, \mathrm{n}=55)$. Obraz pielęgniarki widziany przez witryny internetowe $(28,5 \%, \mathrm{n}=75)$ miał, w opinii badanych największy wpływ na budowanie wizerunku. Większość badanych, bardzo wysoko $(47,1 \%, \mathrm{n}=124)$ i wysoko oceniła $(36,1 \%, \mathrm{n}=95)$ wpływ Internetu na budowanie wizerunku pielęgniarki. Jedna trzecia studentów (31,6\% $\mathrm{n}=83$ ) oceniła siłę Internetu jako korzystną dla wyobrażenia zawodu pielęgniarskiego. Studenci farmacji uważali, że Internet ma bardziej korzystny wpływ na budowanie tego wizerunku. Studenci stomatologii i kierunku lekarskiego częściej uważali, że ten wpływ jest niekorzystny.

Najbardziej rozpowszechnionym elementem obrazu pielęgniarki widzianym przez respondentów w telewizji są strajki $(75,1 \%, \mathrm{n}=187)$. Ponadto telewizja zwraca uwagę także na protesty $(65 \%, \mathrm{n}=171)$ oraz fakt, że zawód pielęgniarki jest gorszy od zawodu lekarza (65\%, $\mathrm{n}=171)$ i jest niedoceniony $(68,1 \%, \mathrm{n}=179)$. W celu poprawy wizerunku w telewizji studenci wskazali przede wszystkim na promowanie osiągnięć zawodowych $(86,7 \%, n=228)$, zmianę stereotypu wizerunku użytego $\mathrm{w}$ filmach i serialach $(77,6 \%, \mathrm{n}=204)$ i zapoznanie $\mathrm{z}$ profesją pielęgniarki $(75,3 \%, \mathrm{n}=198)$ [Tab. 1.].

$\mathrm{W}$ opinii badanych radio również informuje o strajkach i protestach pielęgniarek $(55,1 \%, \mathrm{n}=145)$. Jednak inaczej niż w telewizji porusza się temat błędów pielęgniarek $(27,0 \%, \mathrm{n}=71)$, oraz wskazuje na braki w zatrudnieniu $(33,5 \%, n=88)$. Poprawa wizerunku pielęgniarki może nastąpić poprzez promowanie osiągnięć zawodowych $(81,7 \%, \mathrm{n}=215)$, zmianę stereotypu $(73 \%, \mathrm{n}=192)$ i zapoznanie z profesją pielęgniarki $(72,2 \%, \mathrm{n}=190)$. Nieco rzadziej badani zwracali uwagę na promowanie codziennej pracy $(65 \%, \mathrm{n}=171)$ [Tab. 2.].

Najwięcej badanych wskazywało, że w Internecie najczęściej ukazują się informacje na temat strajków pielęgniarek $(75,7 \%, \mathrm{n}=199)$. Znaczny odsetek badanych wskazywał na brak zatrudnienia pielęgniarek (70,7\%, $\mathrm{n}=186)$. W opinii badanych poprawa wizerunku pielęgniarki, podobnie jak w przypadku innych mediów elektronicznych, może nastąpić poprzez promowanie osiągnięć zawodowych $(85,9 \%, \mathrm{n}=226)$, zmianę stereotypu 


\section{Działania poprawiające wizerunek pielęgniarki w mediach elektronicznych. Opinia młodzieży studiującej na kierunkach medycznych}

- Tab. 1. Opinia respondentów na temat działań zmierzających do poprawy wizerunku w telewizji

\begin{tabular}{|c|c|c|c|c|c|c|}
\hline \multirow{2}{*}{\multicolumn{2}{|c|}{$\begin{array}{l}\text { Działania zmierzające do poprawy } \\
\text { wizerunku w telewizji }\end{array}$}} & \multicolumn{5}{|c|}{ Opinia } \\
\hline & & \multirow{2}{*}{$\begin{array}{c}1 \\
228\end{array}$} & \multirow{2}{*}{$\begin{array}{c}2 \\
29\end{array}$} & \multirow{2}{*}{$\frac{3}{4}$} & \multirow[t]{2}{*}{4} & \multirow[b]{2}{*}{0} \\
\hline Promowanie osiągnięć & $\mathrm{n}$ & & & & & \\
\hline zawodowych & $\%$ & 86,7 & 11,0 & 1,5 & 0,8 & 0 \\
\hline \multirow{2}{*}{$\begin{array}{l}\text { Zmiana stereotypu wizerunku } \\
\text { użytego w filmach i serialach }\end{array}$} & $\mathrm{n}$ & 204 & 43 & 8 & 6 & 2 \\
\hline & $\%$ & 77,6 & 16,3 & 3,0 & 2,3 & 0,8 \\
\hline \multirow{2}{*}{ Zapoznanie z profesją pielęgniarki } & $\mathrm{n}$ & 198 & 46 & 15 & 3 & 1 \\
\hline & $\%$ & 75,3 & 17,5 & 5,7 & 1,1 & 0,4 \\
\hline \multirow{2}{*}{ Promowanie codziennej pracy } & $\mathrm{n}$ & 179 & 69 & 10 & 4 & 1 \\
\hline & $\%$ & 68,1 & 26,2 & 3,8 & 1,5 & 0,4 \\
\hline \multirow{2}{*}{$\begin{array}{l}\text { Przedstawienie rozmów z } \\
\text { pacjentem }\end{array}$} & $\mathrm{n}$ & 172 & 54 & 28 & 7 & 2 \\
\hline & $\%$ & 65,4 & 20,5 & 10,6 & 2,7 & 0,8 \\
\hline \multirow{2}{*}{$\begin{array}{l}\text { Przedstawianie rozmów z } \\
\text { innymi przedstawicielami opieki } \\
\text { medycznej/profesjonalistami } \\
\text { medycznymi }\end{array}$} & $\mathrm{n}$ & 154 & 63 & 33 & 11 & 2 \\
\hline & $\%$ & 58,6 & 24,0 & 12,5 & 4,2 & 0,8 \\
\hline
\end{tabular}

- liczba badanych osób w danej kategori

1-Zdecydowanie tak, 2 - raczej tak, 3 - nie mam zdania, 4 - raczej nie, 5 - zdecydowanie nie

Tab. 2. Opinia respondentów na temat działań zmierzających do poprawy wizerunku w radio

\begin{tabular}{|c|c|c|c|c|c|c|}
\hline \multirow{2}{*}{\multicolumn{2}{|c|}{$\begin{array}{l}\text { Działania zmierzające do poprawy } \\
\text { wizerunku w radio }\end{array}$}} & \multicolumn{5}{|c|}{ Opinia } \\
\hline & & \multirow{2}{*}{$\begin{array}{c}1 \\
215\end{array}$} & \multirow{2}{*}{$\frac{2}{36}$} & \multirow{2}{*}{$\frac{3}{12}$} & \multirow{2}{*}{$\frac{4}{0}$} & \multirow{2}{*}{$\begin{array}{l}5 \\
0\end{array}$} \\
\hline Promowanie osiągnięć & $\mathrm{n}$ & & & & & \\
\hline zawodowych & $\%$ & 81,7 & 13,7 & 4,6 & 0 & 0 \\
\hline \multirow{2}{*}{$\begin{array}{l}\text { Zmiana stereotypu wizerunku } \\
\text { użytego w filmach i serialach }\end{array}$} & $\mathrm{n}$ & 192 & 45 & 17 & 7 & 2 \\
\hline & $\%$ & 73,0 & 17,1 & 6,5 & 2,7 & 0,8 \\
\hline \multirow{2}{*}{ Zapoznanie z profesją pielęgniarki } & $\mathrm{n}$ & 190 & 51 & 18 & 3 & 1 \\
\hline & $\%$ & 72,2 & 19,4 & 6,8 & 1,1 & 0,4 \\
\hline \multirow{2}{*}{ Promowanie codziennej pracy } & $\mathrm{n}$ & 171 & 70 & 15 & 6 & 1 \\
\hline & $\%$ & 65,0 & 26,6 & 5,7 & 2,3 & 0,4 \\
\hline \multirow{2}{*}{$\begin{array}{l}\text { Przedstawienie rozmów z } \\
\text { pacjentem }\end{array}$} & $\mathrm{n}$ & 168 & 57 & 27 & 9 & 2 \\
\hline & $\%$ & 63,9 & 21,7 & 10,3 & 3,4 & 0,8 \\
\hline \multirow{2}{*}{$\begin{array}{l}\text { Przedstawianie rozmów z } \\
\text { innymi przedstawicielami opieki } \\
\text { medycznej/profesjonalistami } \\
\text { medycznymi }\end{array}$} & $\mathrm{n}$ & 151 & 67 & 31 & 11 & 3 \\
\hline & $\%$ & 57,4 & 25,5 & 11,8 & 4,2 & 1,1 \\
\hline
\end{tabular}

$(76 \%, \mathrm{n}=200)$ i zapoznanie z profesją pielęgniarki $(76 \%$, $\mathrm{n}=205)$. Nieco rzadziej badani zwracali uwagę na promowanie codziennej pracy $(71,5 \%, \mathrm{n}=188)$ [Tab. 3.].

Najwięcej badanych zwróciło uwagę na dostępność jako aspekt ważny przy budowaniu strony internetowej lub innego narzędzia. Co czwarty badany zwracał uwagę na popularność $(24,3 \%, \mathrm{n}=64)$, a co piąty na czytelność i oryginalność $(20,4, n=37)$. Ponadto $14,4 \%(n=38)$ zwróciło uwagę na aktywność i aktualność informacji [Tab. 4.].

Większość badanych $(64,6 \%, \mathrm{n}=169)$ uważała, że odpowiedzialnym za poprawę wizerunku pielęgniarek są sami przedstawiciele tej grupy zawodowej, a nie organizacje zawodowe pielęgniarek i położnych $(35,4 \%, \mathrm{n}=93)$. $\mathrm{Z}$ analizy badań wynika, iż 20 respondentów $(7,6 \%)$ znało akcje społeczne lub działania organizacji zawodowych na rzecz poprawy obrazu zawodu pielęgniarki.

Według badanych studentów najważniejszym zadaniem, które powinny przedsięwziąć organizacje zawo-
Tab. 3. Opinia respondentów na temat działań zmierzających do poprawy wizerunku w Internecie

\begin{tabular}{|l|c|c|c|c|c|c|}
\hline \multirow{2}{*}{$\begin{array}{l}\text { Działania zmierzające do poprawy } \\
\text { wizerunku w Internecie }\end{array}$} & \multicolumn{6}{|c|}{ Opinia } \\
\cline { 2 - 7 } $\begin{array}{l}\text { Promowanie osiągnięć } \\
\text { zawodowych }\end{array}$ & 1 & 2 & 3 & 4 & 5 \\
\cline { 2 - 7 } & $\%$ & 226 & 31 & 6 & 0 & 0 \\
\hline $\begin{array}{l}\text { Zmiana stereotypu wizerunku } \\
\text { użytego w filmach i serialach }\end{array}$ & $\mathrm{n}$ & 200 & 50 & 8 & 3 & 2 \\
\cline { 2 - 7 } & $\%$ & 76,0 & 19,0 & 3,0 & 1,1 & 0,8 \\
\hline \multirow{2}{*}{ Zapoznanie z profesją pielęgniarki } & $\mathrm{n}$ & 205 & 43 & 9 & 5 & 1 \\
\cline { 2 - 7 } & $\%$ & 77,9 & 16,3 & 3,4 & 1,9 & 0,4 \\
\hline \multirow{2}{*}{ Promowanie codziennej pracy } & $\mathrm{n}$ & 188 & 60 & 11 & 3 & 1 \\
\cline { 2 - 7 } & $\%$ & 71,5 & 22,8 & 4,2 & 1,1 & 0,4 \\
\hline $\begin{array}{l}\text { Przedstawienie rozmów z } \\
\text { pacjentem }\end{array}$ & $\mathrm{n}$ & 179 & 52 & 23 & 7 & 2 \\
\cline { 2 - 7 } & $\%$ & 68,1 & 19,8 & 8,7 & 2,7 & 0,8 \\
\hline $\begin{array}{l}\text { Przedstawianie rozmów z } \\
\text { innymi przedstawicielami opieki } \\
\text { medycznej/profesjonalistami } \\
\text { medycznymi }\end{array}$ & $\mathrm{n}$ & 162 & 60 & 31 & 8 & 2 \\
\cline { 2 - 7 } & $\%$ & 61,6 & 22,8 & 11,8 & 3,0 & 0,8 \\
\hline
\end{tabular}

$\mathrm{n}$ - liczba badanych osób w danej kategorii

1 - Zdecydowanie tak, 2 - raczej tak, 3 - nie mam zdania, 4 - raczej nie, 5 - zdecydowanie nie

Tab. 4. Opinia respondentów na temat działań, które mogą poprawić wizerunek w Internecie

\begin{tabular}{|l|c|c|}
\hline \multicolumn{1}{|c|}{$\begin{array}{c}\text { Aspekty ważne przy budowaniu strony } \\
\text { internetowej lub innego narzędzia }\end{array}$} & N & $\%$ \\
\hline Czytelność i oryginalność & 37 & 20,4 \\
\hline Popularność & 64 & 24,3 \\
\hline Dostępność & 83 & 31,6 \\
\hline Aktywność i aktualność informacji & 38 & 14,4 \\
\hline Inne & 78 & 29,7 \\
\hline Ogółem & 263 & 100,0 \\
\hline
\end{tabular}

$\mathrm{N}$ - liczba badanych osób w danej kategorii

dowe w celu poprawy wizerunku zawodu były poprawa płac i warunków pracy $(72,2 \%, \mathrm{n}=189)$ oraz większa promocja zawodu w mediach elektronicznych $(73,8 \%$, $\mathrm{n}=193)$, następnie organizowanie kampanii społecznych $(64,3 \%, \mathrm{n}=168)$ oraz utożsamianie pielęgniarek ze środowiskiem zawodowym $(64,3 \%, \mathrm{n}=168)$. Najmniejsze znaczenie przypisano współpracy z firmami Public Relation $(49 \%, n=128)$. Według ankietowanych zadaniami, które muszą podjąć pielęgniarki, $\mathrm{w}$ celu poprawy ich wizerunku są: dbanie o dobrą opinię o zawodzie poprzez ich własny przykład $(39,2 \%, n=103)$ oraz tworzenie $(26,2 \%, n=69)$ np. blogów, forów społecznościowych, internetowych serwisów informacyjnych, zaś $13,3 \%(n=35)$ badanych uważało, że wizerunek może poprawić angażowanie się w pracę organizacji zawodowych.

\section{DYSKUSJA}

Funkcja opiniotwórcza social mediów wytwarza środowisko sprzyjające kształtowaniu lub w zdecydowanym stopniu wywieraniu wpływu na poglądy. Media są decydentem w sprawie, co i jak zostanie opublikowane oraz jaki stopień ważności będzie miała dana informacja [7]. Dobek-Ostrowska zwraca uwagę na to, iż jednym z praw obywatela w państwie demokratycznym jest swoboda wyrażania opinii wsparta prawem do rzetelnej informacji. Sposób realizacji powyższej zasady przez media 
wyznaczana jest zaś przez normy prawne [8]. Prawo do wolności słowa jest chronione przez Konwencję o Ochronie Praw Człowieka i Podstawowych Wolności oraz przez Konstytucję Rzeczpospolitej Polskiej, a także przez Prawo Prasowe [9,10]. Dziennikarz ma obowiązek działać zgodnie z etyką zawodową, szczególną starannością i rzetelnością. Stopień staranności dziennikarza może być różny. Dlatego, gdy pielęgniarka czynna zawodowo popełniła błąd podczas pracy z pacjentem, należy pamiętać o tym, iż przyczynę, dla której tak się stało, dziennikarz może opisać posługując się dowolnie wybranym przez siebie mechanizmem, również niezgodnym z prawdą. Środki masowego przekazu mogą pełnić rolę usługową, ale warunkiem koniecznym dla sukcesu jest ich dobre wykorzystanie.

Większość badanych $(64,6 \%)$ uważała, że to właśnie na pielęgniarkach i pielęgniarzach spoczywa powinność poprawy wizerunku swojego zawodu. Dane te znajduja odzwierciedlenie w wynikach badań Sobczak i Kamińskiej, gdzie według respondentów na pozycję zawodową pielęgniarek wpływa rodzaj podejmowanych działań. Stwierdzono wysoce istotną zależność (chi2 $=24,46$, $\mathrm{df}=4, \mathrm{p}<0,0001)$ rozkładu odpowiedzi na pytanie „Proszę wskazać, która z podanych działalności pielęgniarek najmocniej wpływa na umocnienie ich pozycji zawodowej?”. W grupie studentów najczęstszą odpowiedzią była „społeczna” (54\%), a wśród słuchaczy Uniwersytetu III Wieku najczęstszą odpowiedź stanowiła opcja „naukowa” (37\%) [11]. Podobnie Kołodziej zwraca uwagę na to, iż takie czynniki jak: coraz wyższe wykształcenie, ukończenie studiów czy rozwój medycyny stawiający nowe wyzwania pielęgniarkom są dźwignią pomagającą podnieść społeczny i zawodowy status tej profesji [12]. W badaniach własnych respondenci byli zdania, iż poprawa wizerunku pielęgniarki może nastąpić przede wszystkim poprzez promowanie osiągnięć zawodowych (86,7\%), zmianę stereotypu wizerunku użytego w filmach i serialach $(77,6 \%)$ i zapoznanie $z$ profesją pielęgniarki $(75,3 \%)$. Z powyższych badań wynika, że na etos swojego zawodu pielęgniarki muszą zapracować same, ponieważ status zawodu i szacunek do niego buduje się przede wszystkim wysokim poziomem kompetencji i profesjonalizmu [13]. Bardzo ważne jest określenie swoistego celu, do którego pielęgniarki chcą zmierzać, ale nie zapominając przy tym o tradycji zawodu [14].

Mimo dostępnych narzędzi medialnych, zaobserwować można wyraźny brak wykorzystania mass mediów w celu zwiększenia rangi profesji pielęgniarskiej. Potwierdzeniem są badania Sykut i Dobrowolskiej, z których wynika, iż tylko 24. pielęgniarki pracujące zawodowo (13,3\%) znały akcje społeczne lub działania organizacji na rzecz poprawy wizerunku zawodu [15]. Podobnie niniejsze badania obejmujące studentów pielęgniarstwa (29\%) wskazują na to, iż akcje społeczne związane z poprawą wizerunku pielęgniarek nie są znane dużej liczbie respondentów (7,2\%).

Ponadto studenci zwrócili uwagę na to, że zarówno telewizja, jak i radio przedstawiają środowisko pielęgniarskie w niekorzystnym świetle. Najgorszy przekaz, w opinii badanych, wysyła telewizja (74\%). Należy pamiętać, że szeroko nagłaśniane błędy przy pracy czy inne negatywne doniesienia bardzo szybko potrafią doprowadzić do nieufności a nawet wrogości społecznej[16].

Na zakres wpływu mediów na opinię społeczną ma wpływ przede wszystkim stopień wiedzy i świadomości danej grupy. Telewizja poprzez proponowany przekaz informacji determinuje sposób myślenia, zachowanie, może wywołać gniew, łzy lub radość, skłania do myślenia widzów, wznieca uczucia i motywuje do działania. Słowa wypowiadane zręcznie i splecione w jedną całość sprawiają, że bardzo często odbiorca danego przekazu zatraca samoświadomość i indywidualizm, a zaczyna się posługiwać utartymi sloganami. Odbiorca zaczyna skupiać się jedynie na wydarzeniach, które prezentują środki masowego przekazu często bez poczucia obowiązku w dążeniu do poznania prawdy. To kolejny powód, dla którego w celu poprawy wizerunku pielęgniarek głównym narzędziem powinny być środki masowego przekazu. Takiego zdania również byli respondenci, którzy za receptę na poprawę prestiżu uważają większą promocję w mediach elektronicznych $(73,8 \%)$, następnie organizowanie kampanii społecznych (64,3\%), a co czwarty badany $(26,2 \%)$ uważał, że wpływ ma tworzenie np. blogów, forów społecznościowych, internetowych serwisów informacyjnych.

Mary Adelaide Nutting - pierwsza na świecie Profesor Pielęgniarstwa powiedziała kiedyś: „Pielęgniarstwo jest jedną z najtrudniejszych sztuk. Współczucie może dostarczyć motywacji, ale wiedza jest naszą jedyną mocą i siłą napędową do pracy" [17]. W świetle tych słów rzetelną i prawdziwą wiedzą grupa zawodowa pielęgniarek musi dzielić się z całym społeczeństwem wyprzedzając media, ale jednocześnie posługując się nimi. Środki masowego przekazu nie powinny wykorzystywać wiedzy na temat pielęgniarstwa jako własnej reklamy. To pielęgniarki powinny wykorzystać media, aby ich wizerunek był rzeczywisty, a zatem odbiegał od telewizyjnych czy internetowych stereotypów.

\section{WNIOSKI}

1. Ponad połowa badanych studentów oceniła źle pozycję zawodu pielęgniarskiego. Za taką sytuację w dużej mierze odpowiedzialne są media elektroniczne, które zdaniem respondentów mają bardzo wysoki lub wysoki wpływ na wizerunek pielęgniarek.

2. Badani byli zdania, że zarówno telewizja, jak i radio przedstawiają środowisko pielęgniarskie w złym świetle. Najgorszy przekaz wysyła telewizja a konkretnie wiadomości i doniesienia ze świata.

3. Według badanych za poprawę sytuacji odpowiadają organizacje zawodowe pielęgniarek i położnych oraz same pielęgniarki i pielęgniarze.

4. W celu poprawy wizerunku pielęgniarki są zobowiązane do promowania osiągnięć zawodowych, zmiany stereotypu użytego w serialach i filmach oraz zapoznawania z profesją. W tym celu należy wykorzystać rodzaje mass mediów takie jak: strony internetowe, telewizję i radio. 


\section{PIŚMIENNICTWO/REFERENCES}

1. Dyczewski L. Więź rodzinna a media elektroniczne. Ruch Prawniczy, ekonomiczny i socjologiczny. 2005; LXVII(1): 231, 235.

2. Lemish D. Dzieci i telewizja. Perspektywa globalna. Wydawnictwo Uniwersytetu Jagiellońskiego; 2008.

3. Miller G, Galantem E, Pribram K. Plans and the structure of behavior. New York Holt, 198012.

4. Grabska K, Stefańska W. Sylwetka zawodowa pielęgniarki w opinii pacjentów. Problemy Pielęgniarstwa. 2009; 17(1): 8-12.

5. Centrum Badania Opinii Społecznej: Opinia społeczna na temat badania zaufania publicznego. http://www.cbos.pl/SPISKOM.P0L/2016/K_018_16.PDF (dostęp: 2017.05.27).

6. http://www.gallup.com/poll/1654/honesty-ethics-professions.aspx (dostęp: 2017.05.27).

7. Lepa A. Opinia publiczna, media i zasady etyki. Paedagogia Christiana. 2011; 1(27): 90-93.

8. Dobek-0strowska B. Media masowe w systemie demokratycznym. Dolnośląska Szkoła Wyższa Edukacji Towarzystwa Wiedzy Powszechnej, 2003.

9. Konwencja o Ochronie Praw Człowieka i Podstawowych Wolności sporządzona w Rzymie dnia 4 listopada 1950 r., zmieniona następnie Protokołami nr 3, 5 i 8 oraz uzupełniona Protokołem nr 2. Dz.U. z 1993 r. nr 61, poz. 284

10. Prawo prasowe. Dz.U. z 1984 r. nr 5, poz. 24. Ustawa z dnia 26 stycznia 1984 r.
11. Sobczak M, Kamińska B. Poziom prestiżu zawodowego pielęgniarek w opinii wybranych grup. Problemy Pielęgniarstwa. 2012; 20(2): 218-222.

12. Kołodziej A. Czynniki określające status społeczny pielęgniarek. Hygeia Public Health. 2014; 49(1): 69-74.

13. Grychtoł S, Leszczyńska K. Stereotypy a pozycja zawodowa. Magazyn Pielęgniarki iPołożnej. 2012; 10: 4-5.

14. Kunecka D. Jak Cię widzą tak Cię piszą. Magazyn Pielęgniarki i Położnej. 2011; 10: 4-5.

15. Sykut A. Media elektroniczne w budowaniu wizerunku zawodowego pielęgniarek. Opinia pielęgniarek czynnych zawodowo. Nieopublikowana praca magisterska napisana pod kierunkiem B. Dobrowolskiej.

16. Januszewicz P, Zarzycka D, Binkowska-Bury M, Marć M, Zalewska K. Pielęgniarki i lekarze - życie codzienne i prognozy na przyszłość. Przegląd Lekarski. 2009; 66(7): 469-470.

17. Dahnke M, Dreher M. Philosophy of Science for Nursing Practice, Second Edition: Concepts and Application. New York: Springer Publishing Company; 2016.

Praca przyjęta do druku/Manuscript received: 10.06.2017

Praca zaakceptowana do druku/Manuscript accepted: 28.11.2017

Tłumaczenie/Translation: Beata Chrust 